\title{
Çocuklarda Beta-Laktam Antibiyotiklere Aşırı Duyarlılık Şüphesi ve Çocuk Alerji Klinik Deneyimleri
}

\section{Suspected Hypersensitivity To Beta-Lactam Antibiotics In Children And Clinical Experiences From Pediatric Allergy}

\author{
Ayşegül Ertuğrul (0000-0002-8146-3386), Nevzat Başkaya (0000-0002-5587-0041), \\ Saliha Esenboğa (0000-0003-0562-9863), Serap Özmen (0000-0002-5671-9394) \\ Sağık Bilimleri Üniversitesi, Ankara Dr. Sami Ulus Kadın Doğum, Çocuk Sağlığı ve Hastalıkları Eğitim ve Araştırma Hastanesi, Çocuk Alerji \\ İmmünoloji, Ankara, Türkiye
}

\begin{abstract}
Anahtar kelimeler
Çocuk, beta-laktam alerjisi, penisilin alerjisi, ilaç, alerjisi
\end{abstract}

\section{Keywords}

Beta-lactam allergy, child, drug allergy, penicillin allergy

Geliş Tarihi/Received : 04.12.2020

Kabul Tarihi/Accepted : 25.01.2021

DOI:10.4274/jcp.2021.0001

Yazışma Adresi (Sorumlu Yazar)/

Address for Correspondence:

Uzm. Dr. Ayşegül Ertuğrul, Sağlık Bilimleri Üniversitesi, Ankara Dr. Sami Ulus Kadın Doğum, Çocuk Sağlığı ve Hastalıkları Eğitim ve Araştırma Hastanesi, Çocuk Alerji İmmünoloji, Ankara, Türkiye

\section{$\ddot{O} \mathbf{z}$}

Giriş: Çocuklarda ilaca bağlı aşırı duyarlılık reaksiyonlarına en sık neden gösterilen ilaçlar beta-laktam antibiyotiklerdir(BLA). Ancak, hastaların \%95'inden fazlası uygun bir şekilde değerlendirildiğinde güvenle penisilin grubu ilaçları kullanabilmektedir. Bu çalışmada şüpheli BLA alerjisi nedeniyle başvurmuş hastaların klinik özelliklerini, ilaç alerjisine yönelik yapılan tanısal testleri ve sonuçları incelenerek gerçek BLA alerjisi sıklığını değerlendirmeyi amaçladık.

Gereç ve Yöntem: Çalışmada, üçüncü basamak bir sağlık merkezinde çocuk alerji polikliniğine, bir yillık sürede, şüpheli BLA alerjisi nedeniyle başvurmuş 44 çocuk retrospektif olarak değerlendirildi.

Bulgular: Çalışmaya BLA alerjisi şüphesi ile toplam 44 çocuk (kı/erkek: 24/20) dahil edildi. Hastaların \%38,6'sında $(n=17)$ alerjik hastalık öyküsü, \%36,4'ünde $(n=16)$ ailede alerjik hastalık öyküsü vardı. En sık bildirilen şüpheli ilaç amoksisilin klavulonat (\%75), en sik antibiyotik kullanım nedeni akut tonsillit $(\% 56,8)$ idi. En yaygın klinik tabloyu cilt bulguları $(\% 97,7)$ oluşturmaktaydı. Yapılan alerjik değerlendirme sonucunda toplam 5 hastada (\%11) BLA alerjisi saptand. BLA alerjisi saptanan çocuklar ile saptanmayanlar arasında yaş, cinsiyet, atopi öyküsü ya da ailede ilaç alerjisi öyküsü varlığı açısından anlamlı bir farklılık saptanmadı $(\mathrm{p}>0,05)$.

Sonuç: Tanısal değerlendirme sonrası, sadece öykü ile şüpheli alerjik reaksiyon kabul edilecek olguların gerçekte az bir kısmında BLA aşırı duyarlılığı olduğu gösterilmiştir. BLA'lara karşı alerjik reaksiyon öyküsü olan çocuklarda doğru tanıyı güvenle ortaya koymak ve hastaları gereksiz yere ilaç alerjisi tanısıyla etiketlememek için ayrıntılı bir klinik öykü doğrultusunda uygun ilaç alerjisi değerlendirmesi gerekmektedir.

\footnotetext{
Abstract

Introduction: Beta-lactam antibiotics (BLA) are the most common drugs that cause drug-related hypersensitivity reactions in children. However, more than $95 \%$ of patients can safely use penicillins when properly evaluated. In this study, we aimed to evaluate the actual frequency of BLA allergy by examining the clinical characteristics of the patients, diagnostic evaluation of drug allergy tests and results in patients presenting with suspected BLA allergy.

Materials and Methods: In the study, 44 children who admitted to a pediatric allergy outpatient clinic in a tertiary care center with suspected BLA allergy in a one-year period were evaluated retrospectively.

Results: A total of 44 children (male/female: 24/20) with suspected BLA allergy were included in the study. $38.6 \%(\mathrm{n}=17)$ of the patients had a history of allergic disease, $36.4 \%(n=16)$ had a family history of allergic disease. The most frequently
} 
reported culprit drug was amoxicillin clavulonate $(75 \%)$ and the most common cause of antibiotic usage was acute tonsillitis (56.8\%). Skin findings $(97.7 \%)$ were the most common clinical presentation. As a result of the allergic evaluation, a total of 5 patients $(11 \%)$ were found to have BLA allergy. There was no significant difference between children with BLA allergy and those who were not, in terms of age, gender, atopy or family history of drug allergy $(\mathrm{p}>0.05)$.

Conclusions: After diagnostic evaluation, it has been shown that BLA hypersensitivity is actually present in a small number of cases that are considered to be suspected allergic reactions only with history. In children with a history of allergic reactions to BLAs, an appropriate drug allergy assessment is required in line with a detailed clinical history in order to establish the correct diagnosis confidently and not to label patients with a diagnosis of drug allergy unnecessarily.

\section{Giriş}

Ters ilaç reaksiyonları klinikte sık karşılaşılan sorunlardan biridir. Genel insidansı yatan hastalarda $\% 1,7-50,9$ ve poliklinik başvurularında \%0,5-12,8 arasında rapor edilmiştir (1). İlaç aşırı duyarlılık reaksiyonları, immün mekanizmaların aracılık ettiği, öngörülemeyen ters ilaç reaksiyonlarıdır ve tüm olumsuz ilaç reaksiyonlarının üçte birini oluşturur. Genel popülasyonda prevalansı $\% 7$ olarak rapor edilmiştir (2). Çocuklarda ilaca bağlı aşırı duyarlılık reaksiyonlarına en sık neden gösterilen ilaçlar betalaktam antibiyotiklerdir (BLA) (3).

BLA'lara karşı aşırı duyarlılık reaksiyonları, reaksiyonun ortaya çıkış süresine göre erken veya geç tip olarak sınıflandırılır. Erken reaksiyonlar ilaç uygulamasından sonra ilk bir saat içinde ortaya çıkan IgE aracılı reaksiyonlardır. Klinikte tipik olarak ürtiker, anjioödem, rinit, konjonktivit, laringeal ödem, bronkospazm, gastrointestinal semptomlar (bulant, kusma, ishal, karın ağrısı) gözlenir. Geç tip reaksiyonlar T-hücre aracılıdır. İlaç uygulamasından bir saat sonra ortaya çıkan reaksiyonlardır (4,5). BLA'lara karşı geç reaksiyonlar genellikle kendi kendini sınırlar ve en s1k makülopapüler döküntüler görülür $(5,6)$.

Şüpheli BLA alerji öyküsü olan çocukların alerjik değerlendirme sonrası \%90'ından fazlasının ilacı sorunsuzca kullanabildiği görülmüştür $(7,8)$. Bu durumun sebeplerinden biri, çocuklarda enfeksiyöz (bakteriyel veya viral) sebeplerle ortaya çıan döküntülerin BLA alerjisi olarak teşhis edilmesidir $(4,6,9,10)$. Diğer bir sebep ise zaman içinde mevcut BLA duyarlılığının kaybolmasıdır. BLA alerjisi olan hastaların yaklaşık \%50'si beş yılda, \%80'i ise on yılda duyarlılıklarını kaybederler (11).

BLA alerji şüphesi olan çocuklara alerjik değerlendirme yapılmaması ve non-BLA antibiyotiklerin kullanımı geniş spektrumlu antibiyotik seçimlerine neden olmaktadır. Bu durum artmış antimikrobiyal direnç, artmış Clostridium difficile enfeksiyonları, hastane kalış süresinde uzama ve artmış sağlık harcamalarıyla sonuçlanmaktadır $(12,13,14)$. Bu nedenle şüpheli ilaç alerjisi nedeniyle başvuran hastalar klinik öykülerine göre in vitro ve in vivo tanısal testler ve kontrendikasyon yoksa ilaç provokasyon testleri (IPT) ile değerlendirilmelidir. IPT, ilaç alerjilerinin tanısı için "altın standart" olarak kabul edilir $(3,6,15)$.

$\mathrm{Bu}$ çalışmada üçüncü basamak bir sağlık merkezinde çocuk alerji polikliniğine, bir yıllık sürede, şüpheli BLA alerjisi nedeniyle başvurmuş çocuklar değerlendirilmiştir. Çalışmada hastaların klinik özellikleri, ilaç alerjisine yönelik yapılan tanısal testleri ve bu testlerin sonuçları incelenerek gerçek BLA alerjisi sıklığının değerlendirilmesi amaçlanmaktadır.

\section{Gereç ve Yöntem}

01.01.2019 - 31.12.2019 tarihleri arasında üçüncü basamak bir çocuk alerji polikliniğine şüpheli BLA alerjisi nedeniyle başvuran hastaların tıbbi kayıtları geriye dönük olarak incelendi. Ağır kutanöz ilaç reaksiyonu (Stevens-Johnson sendromu, toksik epidermal nekrolizis, akut generalize egzantematöz püstülozis, eozinofili ve sistemik semptomların eşlik ettiği ilaç reaksiyonu) gözlenen hastalar çalışma diş1 bırakıldı. Hastaların demografik ve klinik özellikleri kaydedildi. Şüpheli BLA alerjisini aydınlatmak için hastalara uygulanan tanısal testlerin (şüpheli ilaç/ alternatif ilaç ile deri testi, spesifik IgE, IPT) sonuçları kaydedildi.

\section{Laboratuvar Bulgulart ve Deri Prik Testleri}

Avrupa İlaç Alerjisi Grubu (ENDA) önerileri 1şığında, ilaç alımı sonrası ilk 1 saatte reaksiyon gözlenen hastalar erken reaksiyon, 1 saatten geç reaksiyon gözlenenler hastalar geç reaksiyon 
olarak kabul edildi. Şüpheli ilaç ile deri prik testi (DPT) ve intradermal testi (IDT) ebeveyn ve hasta onamı alındıktan sonra ENDA ve Avrupa Alerji ve Klinik İmmünoloji Akademisi (EAACI) rehberleri önerileri doğrultusunda uyguland $1(5,16)$. Penisilin ile deri testleri majör determinant [Penisiloilpolilizin (PPL)(5X10-5M)] ve minör determinant karışımı (MDM) [Penisilloat, Penilloat (2X10-2M) (Diater, Madrid, İspanya)] ile uyguland. Majör ve minör determinant testleri uygulanan hastalara şüpheli ilaç reaksiyonuna göre penisilin G (25.000 $\mathrm{IU} / \mathrm{mL}$ konsantrasyon), amoksisilin/amoksisilin klavulonat $(20 \mathrm{mg} / \mathrm{mL}$ konsantrasyon amoksisilin) ve sefalosporin $(20 \mathrm{mg} / \mathrm{mL}$ konsantrasyon) ile DPT ve IDT yapıldı. DPT ve IDT önkol volar yüze uygulandı. 15-20 dakika sonra değerlendirildi. İlaç ile DPT, $3 \mathrm{~mm}$. üzerinde papül ve beraberinde eritem varlığında pozitif kabul edildi. İlaç ile IDT, uygulama sonrası hemen ölçülen endurasyona göre $3 \mathrm{~mm}$ artış gösteren endurasyon ve eritem varlığında pozitif kabul edildi. Pozitif kontrol olarak histamin (10 mg/mL) (ALK-Abellò, Madrid, İspanya) ve negatif kontrol olarak \%0.9 salin çözeltisi kullanıldı. İlaç ile İDT geç reaksiyon öyküsü olanlarda 48-72. saatte tekrar değerlendirildi.

Penisilloil G, penisilloil V ve amoksisilin spesifik IgE floroimmunoassay (Immulite CLIA Siemens, Almanya) kullanılarak elde edildi. 0,35 kUA/l'in üzerindeki değerler pozitif kabul edildi.

\section{İlaç Provokasyon Testleri}

İlaç provokasyon testleri hastanın kliniğine göre deri testleri yapılmadan direkt ya da DPT ve İT yapılıp negatif saptandıktan sonra uygulandı. Total doz, 3-5 basamak arasında, 30 dakika aralarla kademeli doz artımı ile ENDA/EAACI rehberlerinin önerdiğ $i$ dozlarda uyguland $1(5,16)$. Dozlar, pozitif bir reaksiyon elde edilene kadar veya hastanın vücut ağırlığına göre hesaplanan toplam terapötik doza ulaşana kadar arttırıldı. Deri (ürtiker, anjioödem, makülopapüler döküntü, vb.), solunum (öksürük, hırıltılı solunum, dispne vb.), kardiyovasküler (hipotansiyon, taşikardi vb.) ve gastrointestinal (karın ağrısı, kusma, ishal vb.) sistem belirtileri ortaya çıktığında test durduruldu ve pozitif kabul edildi. Geç tip reaksiyon öyküsü olan hastalarda şüpheli antibiyotik ile provokasyona evde 3-5 gün daha devam edildi. İlaca devam ederken geç dönemde semptom gelişmesi durumunda, ebeveynlere tedaviyi durdurmaları ve hastaneye başvurmaları tavsiye edildi.

\section{Istatistiksel Analiz.}

Verilerin analizi, IBM SPSS 15 kullanılarak yapıldı. Kantitatif değişkenler, ortanca/ortalama ve çeyrekler arası aralı/minimum-maksimum olarak özetlendi; kategorik değişkenler sayı (\%) olarak belirtildi. Nitel değişkenlerin alt gruplar arasındaki dağılımları ki kare testi kullanılarak karşılaştırıldı. Tüm testler için istatistiksel anlamlılık $\mathrm{p}<0,05$ olarak kabul edildi.

\section{Bulgular}

Çalışmaya BLA alerjisi şüphesi ile toplam 44 çocuk (kız/erkek 24/20) dahil edildi. Çalışmaya alınan çocukların ortanca (minimum-maksimum) yaşı $67(5$ - 197) aydı. Hastaların \%38,6'sında $(n=17)$ kişisel alerjik hastalık, \%36,4'ünde $(\mathrm{n}=16)$ ailede alerjik hastalık öyküsü vardı. Çocuklarda gözlenen en sık alerjik hastalık astım, ailelerde gözlenen en sık alerjik hastalık ilaç alerjisi idi. Hastaların demografik özellikleri Tablo 1'de özetlendi.

En sık bildirilen şüpheli ilaç amoksisilin klavulonat (\%75), en sık antibiyotik kullanım nedeni akut

Tablo 1. Şüpheli beta-laktam alerjisi ile başvuran hastaların demografik özelllikleri

\begin{tabular}{ll}
\hline & $\begin{array}{l}\text { Hasta sayısı=44 } \\
\mathrm{n}(\%)\end{array}$ \\
\hline Cinsiyet & $24(54,5)$ \\
Kız & $67(30,2-114,5)$ \\
Yaş (ay)* & $17(38,6)$ \\
Alerjik hastalık & $7(15,9)$ \\
Astım & $3(6,8)$ \\
Atopik dermatit & $2(4,5)$ \\
Alerjik rinit & $2(4,5)$ \\
Kronik ürtiker & $2(4,5)$ \\
Atopik dermatit + Kronik ürtiker & $1(2,3)$ \\
Besin alerjisi & $16(36,4)$ \\
Ailede alerjik hastalık & $8(18,3)$ \\
İlaç alerjisi & $3(6,8)$ \\
Alerjik rinit & $2(4,5)$ \\
Atopik dermatit & $1(2,3)$ \\
Kronik ürtiker & $1(2,3)$ \\
Venom alerjisi & \\
\hline *Ortanca (çeyrekler arası aralı) &
\end{tabular}


tonsillit $(\% 56,8)$ idi. Reaksiyona neden olan şüpheli ilaçlar ve kullanım endikasyonları Tablo 2'de verildi. Hastaların \%56.8'sinde şüpheli ilaç reaksiyonu ilaç alımından sonra ilk 48 saatte ortaya çıktı. En yaygın klinik tabloyu cilt bulguları $(\% 97,7)$ oluşturmaktaydı. Üç hastada $(\% 6,8)$ birden fazla sistem tutulumu ile anafilaksi gözlendi. İlaç reaksiyonu sonrası hastaların $\% 77,3$ 'ü (n=34) hastaneye başvurdu, \%6,8'i $(\mathrm{n}=6)$ ilaç reaksiyonu nedeniyle hastanede yatırılarak izlendi. Hastaların klinik özellikleri Tablo 3'de gösterildi. Yapılan alerjik değerlendirme ve İPT sonucunda toplam 5 hastada (\%11) BLA alerjisi saptandı. Bu hastaların aşırı duyarlılık reaksiyonları bir hastada IDT ile, dört hastada ise IPT ile gösterildi. Hastaların reaksiyon öyküsü ile alerjik değerlendirme arasında geçen süre ortancas1 (minimum-maksimum) 6 (1-125) ayd1. Hastaların 32'sinde (\%73) in vivo testler öncesinde, penisiloil $\mathrm{G}$, penisiloil $\mathrm{V}$ ya da amoksisilin spesifik IgE bakıld1, hiçbir hastada pozitiflik saptanmadı.

Tablo 2. Alerjik reaksiyona neden olan beta-laktam antibiyotikler ve kullanım endikasyonları

\begin{tabular}{ll}
\hline & $\begin{array}{l}\text { Hasta sayısı=44 } \\
\mathrm{n}(\%)\end{array}$ \\
\hline Reaksiyona neden olan şüpheli ilaç & \\
Amoksisilin klavulonat & $33(75)$ \\
Seftriakson & $2(4,5)$ \\
Sefuroksim & $2(4,5)$ \\
Ampisilin & $1(2,3)$ \\
Fenoksimetilpenisilin & $1(2,3)$ \\
Penisilin G & $1(2,3)$ \\
Sefiksim & $1(2,3)$ \\
Sefaleksin & $1(2,3)$ \\
Bilinmiyor & $2(4,5)$ \\
Endikasyon & \\
Akut tonsillit & $25(56,8)$ \\
Pnömoni & $4(9,1)$ \\
Akut otitis media & $4(9,1)$ \\
İdrar yolu enfeksiyonu & $3(6,8)$ \\
Bakteriyemi & $2(4,5)$ \\
Diş absesi & $1(2,3)$ \\
Lenfadenit & $1(2,3)$ \\
Akut romatizmal ateş profilaksisi & $1(2,3)$ \\
Yumuşak doku enfeksiyonu & $1(2,3)$ \\
Bilinmiyor & $2(4,5)$ \\
\hline &
\end{tabular}

Hastaların İPT öncesinde \%27'sine $(n=12)$ majör ve minör determinant ile, \%41'ine $(n=18)$ şüpheli ilaç ile deri testleri yapıldı. Deri testi yapılmadan direkt İPT yapılan hastaların yaşı [ortanca (çeyrekler arası aralık) 43 ay (15-60)], deri testi yapıldıktan sonra İPT yapılanların yaşından [ortanca (çeyrekler arası aralık) 118 ay (90-148)] anlamlı olarak düşüktü $(\mathrm{p}<0.001)$. Yapılan DPT ve IDT sonucunda bir hastada seftriakson ile IDT pozitifliği saptand. Otuz iki hastaya şüpheli BLA ile IPT yapılarak 29 hastada başvuru nedeni olan şüpheli ilaç ile alerji olmadığ 1 gösterildi. 32 hastanın üçünde BLA alerji şüphesi olan ilaç ile provokasyon testinde pozitiflik saptandi. Üç hastanın ikisine alternatif BLA ile IPT yapılarak kullanabileceği güvenli bir BLA belirlendi. Bir hasta takiplerine gelmediği için alternatif güvenli ilaç belirlenemedi. 11 hastada (\%25) şüpheli ilaç ile test yapılmadı, alternatif bir BLA ile İTT yapıld1. 10 hastada alternatif güvenli ilaç ile provokasyon testinde pozitiflik saptanmazken, bir hastada alternatif ilaç ile provokasyon testinde pozitiflik saptand1. Hastaların \%65.9'unda $(n=29)$

Tablo 3. Şüpheli beta-laktam alerjisi ile başvuran hastaların klinik özellikleri

\begin{tabular}{ll}
\hline & $\begin{array}{l}\text { Hasta sayısı=44 } \\
\mathrm{n}(\%)\end{array}$ \\
\hline Reaksiyon görülme yaşı (ay)* & $36(15,7-84)$ \\
$\begin{array}{l}\text { Reaksiyondan başvuruya kadar geçen } \\
\text { süre (ay)* }\end{array}$ & $2(1-5)$ \\
Illaç alımı ile gözlenen klinik bulgu & \\
Cilt bulguları & $43(97,7)$ \\
$\quad$ Ürtiker-anjioödem & $19(43,1)$ \\
$\quad$ Makulopapüler-non spesifik döküntü & $24(54,5)$ \\
Solunum bulguları & $3(6,8)$ \\
Gastrointestinal sistem bulguları & $2(4,5)$ \\
Kardiyovasküler sistem bulguları & $1(2,3)$ \\
Anafilaksi & $3(6,8)$ \\
Illaç uygulama yolu & \\
Oral & $40(90,9)$ \\
Parenteral & $4(9,1)$ \\
Illaç alımı ile reaksiyon arasındaki süre & \\
<1 saat & $8(18,6)$ \\
1-6 saat & $8(18,6)$ \\
>6 saat & $11(25)$ \\
Bilinmiyor & $17(38,6)$ \\
\hline *ortanca ve çeyrekler arası aralı) & \\
\hline
\end{tabular}


BLA alerji şüphesi ortadan kalkarken, \%22,7'sine $(n=10)$ şüpheli ilaçtan sakınmalarına karşın güvenli kullanabilecekleri bir BLA önerisinde bulunulmuştur. DeritestiveyaİPT'sinde pozitiflik saptanan beş hastanın ise ikisinde güvenli kullanabilecekleri alternatif BLA saptanmıştır. Sonuç olarak 44 hastadan sadece üçü tüm BLA' lardan kaçınmaktadır. Bu hastalardan biri şüpheli ilaç ile pozitif reaksiyon gözlendikten sonra takiplerine gelmemiştir, ikisi alternatif BLA'larla ilaç testi için aile onamı olmadığından tüm BLA'lardan kaçınmaktadır. BLA duyarlılı̆̆ı saptanan beş hastanın klinik ve laboratuvar özellikleri Tablo 4'de verildi. BLA alerjisi saptanan ve saptanmayan hastaların özelliklerinin karşılaştırılması Tablo 5'de gösterildi.

\section{Tartışma}

Çalışmamızda BLA alerji şüphesi ile başvuran çocuklarda, deri testleri ve/veya İPT ile kanitlanan BLA alerjisi oran $1 \% 11$ olarak bulundu. Bu veri alerjik değerlendirme yapılmadan sadece öykü ile şüpheli kabul edilecek olguların gerçekte az bir kısmında BLA aşırı duyarlılığı olduğunu göstermektedir. BLA'lara karşı alerjik reaksiyon öyküsü olan çocuklarda doğru tanıyı güvenle ortaya koymak, hastaları gereksiz yere ilaç alerjisi tanısıyla etiketlememek ve alternatif tedavilerin istenmeyen etkilerini engellemek için ayrıntılı bir klinik öykü doğrultusunda uygun ilaç alerjisi değerlendirmesi gerekmektedir (17-20).

Çok sayıda hasta penisilin alerjisi olarak etiketlenmesine rağmen, hastaların \%95'inden fazlası uygun bir şekilde değerlendirildiğinde güvenle penisilin grubu ilaçları kullanabilmektedir (21).
Literatürde BLA ile kanıtlanmış aşırı duyarlılık oranı \%6-\%16 arasında değişmektedir. (10,22-24). Çocuklarda BLA' ya karşı ilaç aşırı duyarlılığının tahmini prevalansı \%1-10 arasında bildirilmiştir ve çalışma grubumuz da bu oranı desteklemektedir (6).

Çalışmamızdaliteratüre benzerolaraken sıkşüpheli BLA amoksisilin olarak saptandı. Hastalarımızda yaş, cinsiyet, atopi öyküsü ya da ailede ilaç alerjisi öyküsü varlığ 1 , Ponvert (23) ve ark. ile Zambonino (24) ve ark.'nın yaptıkları çalışmaya benzer olarak gerçek ilaç aşırı duyarlılığı ile bir ilişki göstermemektedir. Çocuklarda en sık bildirilen antibiyotik ilişkili alerjik reaksiyonlar, genellikle erken yaşta, tedavinin ilk haftasında geç dönemde ortaya çıkan cilt semptomları ile bulgu verir $(6,25)$. Literatüre benzer şekilde hasta grubumuzun \%97,7'sinde gözlenen reaksiyon ürtiker veya makulopapüler erüpsiyon olarak cilt bulguları şeklindeydi. Hastaların üçünde indeks reaksiyon anafilaksi kliniğinde olup bu hastaların ikisinde $\mathrm{BL}$ duyarlılığ 1 (seftriakson ve benzatin benzil penisilin) yapılan testlerle gösterildi. Üçüncü hastanın kliniğinde anafilaksi, seftriakson ve amikasin eş zamanlı alındıktan sonra gelişti. Seftriakson ile deri testi negatif bulunan hastanın amikasin ile yapılan deri testlerinde pozitiflik saptandı ve amikasin anafilaksiden sorumlu kabul edildi. Sonuç olarak anafilaksi kliniği gözlenen üç hastanın hepsinde ilaç alerjisi saptandı. Bu durum çoklu sistem tutulumu ya da ağır klinikte bir alerjik reaksiyon ile başvuran hastaların değerlendirilmesinin gerçek alerjik reaksiyonlar açısından özellikle önem taşıdığını göstermektedir.

\begin{tabular}{|c|c|c|c|c|c|c|c|c|}
\hline \multirow[b]{2}{*}{ Hasta } & \multirow{2}{*}{$\begin{array}{l}\text { Cinsiyet/ } \\
\text { reaksiyon } \\
\text { yaşı (ay) }\end{array}$} & \multirow{2}{*}{$\begin{array}{l}\text { Şüpheli ilaç/ } \\
\text { gözlenen } \\
\text { reaksiyon }\end{array}$} & \multirow{2}{*}{$\begin{array}{l}\text { Reaksiyon } \\
\text { zamanı }\end{array}$} & \multirow{2}{*}{$\begin{array}{l}\text { Spesifik IgE } \\
\text { PenV/G/ } \\
\text { Amoksisilin }\end{array}$} & \multicolumn{2}{|c|}{ Deri testi } & \multicolumn{2}{|l|}{ İPT sonuç } \\
\hline & & & & & $\begin{array}{l}\text { PPL/ } \\
\text { MDM }\end{array}$ & Şüpheli ilaç & $\begin{array}{l}\text { Şüpheli } \\
\text { İlaç/ Reaksiyon }\end{array}$ & $\begin{array}{l}\text { Alternatif ilaç/ } \\
\text { Reaksiyon }\end{array}$ \\
\hline 1 & K1z/121 & $\begin{array}{l}\text { Seftriakson/ } \\
\text { Anafilaksi }\end{array}$ & $<1$ saat & Neg & Neg & $\begin{array}{l}\text { Seftriakson } \\
\text { IDT+ }\end{array}$ & {$[-]$} & {$[-]$} \\
\hline 2 & K1z/147 & $\begin{array}{l}\text { Penisilin G/ } \\
\text { Anafilaksi }\end{array}$ & 1-6 saat & Neg & $\mathrm{Neg}$ & Neg & $\begin{array}{l}\text { Penisilin G } \\
\text { Anafilaksi }\end{array}$ & $\begin{array}{l}\text { Ko-amoksilav } \\
(-)\end{array}$ \\
\hline 3 & $\mathrm{~K} 1 \mathrm{z} / 72$ & $\begin{array}{l}\text { Ko-amoksilav/ } \\
\text { MPE }\end{array}$ & $>6$ saat & $\mathrm{Neg}$ & {$[-]$} & {$[-]$} & $\begin{array}{l}\text { Ko-amoksilav } \\
\text { Ürtiker }\end{array}$ & $\begin{array}{l}\text { Sefuroksim } \\
(-)\end{array}$ \\
\hline 4 & $\mathrm{~K} 1 \mathrm{z} / 15$ & $\begin{array}{l}\text { Ko-amoksilav/ } \\
\text { MPE }\end{array}$ & $>6$ saat & {$[-]$} & {$[-]$} & {$[-]$} & $\begin{array}{l}\text { Ko-amoksilav } \\
\text { Ürtiker }\end{array}$ & {$[-]$} \\
\hline 5 & $\mathrm{~K} 1 \mathrm{z} / 30$ & $\begin{array}{l}\text { Sefaleksin/ } \\
\text { Ürtiker }\end{array}$ & $>6$ saat & {$[-]$} & {$[-]$} & {$[-]$} & {$[-]$} & $\begin{array}{l}\text { Ko-amoksilav } \\
\text { Ürtiker }\end{array}$ \\
\hline
\end{tabular}




\begin{tabular}{|c|c|c|c|}
\hline & $\begin{array}{l}\text { Beta laktam alerjisi } \\
\text { saptanan } \\
(\mathrm{n}=5)\end{array}$ & $\begin{array}{l}\text { Beta laktam alerjisi } \\
\text { saptanmayan } \\
(\mathrm{n}=39)\end{array}$ & $\mathrm{p}$ \\
\hline Başvuru yaşı (ay) * & $72(23-136)$ & $65(31-110)$ & 0,767 \\
\hline \multicolumn{4}{|l|}{ Cinsiyet $* *$} \\
\hline Kiz & $5(100)$ & $19(48,7)$ & \multirow{2}{*}{0,053} \\
\hline Erkek & - & $20(51,3)$ & \\
\hline Alerjik hastalık varlı̆̆ı $* *$ & - & $17(43,6)$ & 0,139 \\
\hline Ailede alerjik hastalık varlığı** & - & $16(42,1)$ & 0,139 \\
\hline Ailede ilaç alerjisi öyküsü*** & - & 8 & 0,565 \\
\hline Reaksiyon yaşı (ay) * & $72(22,5-134)$ & $35(15-84)$ & 0,309 \\
\hline İPT yaşı (ay)* & $79(23-136,5)$ & $65(31-110)$ & 0,781 \\
\hline Reaksiyon-İPT arası süre (ay) * & $4(2,5-6)$ & $7(3-24)$ & 0,128 \\
\hline İlaç reaksiyonu nedeniyle hastane yatış ${ }^{* *}$ & $3(60)$ & $3(8,6)$ & 0,018 \\
\hline \multicolumn{4}{|l|}{ Klinik bulgu $* *$} \\
\hline Ürtiker/anjiyoödem & $2(40)$ & $17(43,5)$ & \\
\hline MPE/nonspesifik döküntü & $3(60)$ & $21(53,8)$ & \\
\hline GIS bulgusu & - & $2(5,1)$ & \\
\hline KVS bulguları & - & $1(2,5)$ & \\
\hline Solunum bulgusu & $2(40)$ & $1(2,5)$ & \\
\hline Anafilaksi & $2(40)$ & $1(2,6)$ & \\
\hline \multicolumn{4}{|l|}{ İlaç ile reaksiyon gözlenen gün $* *$} \\
\hline 1.gün & $2(40)$ & $10(25,6)$ & \\
\hline 2.gün & $1(10)$ & $12(30,8)$ & \\
\hline 3.gün ve sonrası & $2(20)$ & $11(28,2)$ & \\
\hline Bilinmiyor & - & $6(15,4)$ & \\
\hline \multicolumn{4}{|l|}{ Son ilaç dozu ile reaksiyon arası süre ** } \\
\hline$<1$ saat & $1(20)$ & $7(17,9)$ & \\
\hline $1-6$ saat & $1(20)$ & $7(17,9)$ & \\
\hline$>6$ saat & $2(40)$ & $9(23,1)$ & \\
\hline Bilinmiyor & $1(20)$ & $16(41)$ & \\
\hline
\end{tabular}

Şüpheli BLA alerjisinde tanısal değerlendirme için yapılacak tetkikler, hastanın klinik reaksiyonuna göre serum spesifik IgE ölçümü, deri testleri ve ilaç provokasyon testleridir $(6,15)$. Hastalarımızın IPT öncesi \%73'ünde ilaç spesifik IgE değerlendirmesi yapıldı ancak gerçek BL duyarlılığı olan hastalar dahil olmak üzere hiçbir hastada pozitiflik saptanmadi. Spesifik IgE testlerinin sensitivitesi, indeks reaksiyonun şiddeti ile korelasyon gösterecek şekilde değişken (\%0-50) ve düşüktür ancak deri testi uygulamasının kontrendike olduğu durumlarda ya da yüksek riskli sistemik reaksiyon öyküsü olan hastalarda alerjik değerlendirmenin sensitivitesini arttırmak için kullanılabilirler (26). Hastalarımızın tanısal değerlendirmesinde ilk 1 saat içinde IgE aracılı semptom tanımlayanların tümüne deri testleri sonrasında İPT yapılmış olmakla birlikte geç reaksiyonların çoğunda deri testleri 
yapılmaksızın IPT yapıldı. Çalışma grubumuzda deri testi yapılmadan IPT yapılanların yaşı anlamlı olarak daha küçük saptandı. Bu durumun, test seçiminde ilaç ile gözlenen indeks reaksiyonun özelliği dışında, küçük çocuklarda pratikte İDT'leri uygulamanın güçlüğünden de kaynaklandığını düşünmekteyiz. Sondönemde yapılmışçalışmalarda, özellikle çocuklarda BLA'larla gözlenen orta-hafif şiddette hipersensitivite reaksiyonlarında ya da makulopapüler erüpsiyon veya geç ürtiker gibi geç tip alerjik reaksiyonlarda deri testi yapmadan IPT yapmanın güvenli olduğu gösterilmiştir $(27,28,29)$. Çalışma grubumuzda deri testi basamağı atlanarak IPT yapılan 26 hastadan üçünde (\%12) cilt ile sınırlı bulgularla pozitiflik saptandı. Bu üç hastanın hepsinde indeks reaksiyon 6 saatten geç olup, IPT testinde ağır alerjik reaksiyon ya da çoklu sistem tutulumu gözlenmedi. Klinik pratikte özellikle okul öncesi yaş grubunda IDT uygulamaları güç ve zaman alıcı olduğundan, BLA'lar ile gelişen geç ve hafif form alerjik reaksiyonlarda deri testi basamağının atlanarak İPT yapılmasının tanı sürecini kolaylaştıran pratik bir yaklaşım olduğunu düşünmekteyiz. Siew ve ark. (30) BL alerjisinde deri testi etkinliğini değerlendirdikleri çalışmalarında, ilaç reaksiyonunun anafilaksi şiddetinde olmaması, şüpheli ilacın adının hatırlanamaması ve reaksiyon ile test arasında bir yıldan fazla süre bulunması durumunda Tip I BL alerjisi negatif prediktif değerini $(\% 98,4)$, deri testlerinin negatif prediktif değeri $(\% 98,9)$ ile benzer bulmuşlardır. Bu çalışmada, tanımlanan özelliklere ek olarak deri testi uygulamak IPT için risk-fayda oranına katkı sağlamamıştır.

Literatürde ortak BL halkası ile ilişkili çapraz reaksiyon nedeniyle tüm beta-laktamlara (BL) $\operatorname{IgE}$ aracılı alerjik reaksiyon oldukça nadirdir. Daha sık görülen ise yan zincirlerdeki yapısal benzerlik nedeniyle ortaya çıkan çapraz reaksiyondur (31). Hastalarımızdan BL alerjisi saptanan beş vakanın ikisinde İPT ile doğrulanmış güvenli alternatif BL belirlendi. Bu hastalardan biri amoksisilin klavulonat ile geç makulopapüler erüpsiyon öyküsü olan hastadır. $\mathrm{Bu}$ hastaya (ilaç reaksiyonu sırasında bakılan EBV serolojisinin pozitif olması nedeniyle) deri testleri yapılmadan direkt şüpheli ilaç ile provokasyon yapıldı ve ürtiker gözlendi, sonrasında ortak yan zincir içermeyen sefuroksim ile IPT yapıldı ve reaksiyon gözlenmedi. Güvenli alternatif belirlenen diğer hasta ise akut romatizmal ateş profilaksisi nedeniyle aylık benzatin benzil penisilin (Pen G) profilaksisi uygulanan hastadır. Bu hastada PPL, MDM ve pen $\mathrm{G}$ ile deri testleri negatif bulunduktan sonra penisilin $\mathrm{V}$ ile IPT testi yapıldı. Penisilin V ile IPT negatif bulunduktan sonra Pen $G$ ile provokasyon yapıldı. Hastada, Pen G intramuskuler olarak uygulandiktan 4 saat sonra ürtiker ve solunum sıkıntısı gözlendi. İzlemde hastanın amoksisilin klavulonat ile deri testleri ve oral provokasyonu negatif saptand. Bu hastada gözlenen duyarlılığın ana BL halkası ya da yan zincir dışında farklı bir yapıdan kaynaklandığııı düşünmekteyiz. Beta-laktam alerjisi tespit edilen diğer bir olgu ise şüpheli ilaç (sefaleksin) ile testi atlanarak alternatif olarak çocukluk çağında sık kullanılan bir BL olan amoksislin klavulonat ile İPT yapılan ve ürtiker gözlenen hastadır. Bu hastada sefaleksin ve amoksisilinklavulonat arasındaki çapraz reaksiyonun benzer yan zincir yapısı nedeniyle olduğunu düşünülmekteyiz. Bu hastaya ortak yan zincir içermeyen bir grup BLA ile ilaç testlerinin yapılması planlandı.

\section{Sonuç}

Çocuklarda ilaç alerjileri etiyolojisinde en sik karşılaşan ajanların başında BLA'lar gelmektedir. Ancak şüpheli reaksiyonların çok az bir kısmında doğrulanmış gerçek ilaç alerjisi saptanır. Çalışmamızda şüpheli BLA reaksiyonlarının \%11'inde ilaç alerjisi doğrulanmıştır. $\mathrm{Bu}$ nedenle BLA ile şüpheli alerjik reaksiyon öyküsü olan çocuklar değerlendirilerek gereksiz yere ilaç alerjisi tanısı ile etiketlenmemelidir. Sonuç olarak BL'lara karşı şüpheli alerjik reaksiyonu olan çocuklarda doğru tanıyı koymak ve potansiyel hayatı tehdit edici reaksiyonları önlemek için ayrıntılı klinik öykü doğrultusunda uygun tanısal değerlendirme mutlaka gereklidir.

\section{Etik}

Etik Kurul Onayı: 01.01.2019 - 31.12.2019 tarihleri arasında üçüncü basamak bir çocuk alerji polikliniğine şüpheli BLA alerjisi nedeniyle başvuran hastaların tıbbi kayıtları geriye dönük olarak incelendi.

Çıkar Çatışması: Yazarlar tarafından çıkar çatışması bildirilmemiştir.

Finansal Destek: Yazarlar tarafından finansal destek almadıkları bildirilmiştir. 


\section{Kaynaklar}

1. Ferner RE, McGettigan P. Adverse drug reactions. BMJ. 2018: 6;363:k4051.

2. Demoly P. Drug allergies - Unknown dangers to patients. Expert Opinion on Drug Safety. 2008; 7:347-50.

3. Joint Task Force on Practice Parameters; American Academy of Allergy, Asthma and Immunology; American College of Allergy, Asthma and Immunology; Joint Council of Allergy, Asthma and Immunology. Drug allergy: an updated practice parameter. Ann Allergy Asthma Immunol. 2010;105(4):259-73.

4. Khan DA, Banerji A, Bernstein JA, Bilgicer B, Blumenthal K, Castells $\mathrm{M}$ et al. Cephalosporin Allergy: Current Understanding and Future Challenges. J Allergy Clin Immunol Pract. 2019;7(7):2105-14.

5. Demoly P, Adkinson NF, Brockow K, Castells M, Chiriac AM, Greenberger PA et al. International Consensus on drug allergy. Allergy. 2014;69(4):420-37.

6. Gomes ER, Brockow K, Kuyucu S, Saretta F, Mori F, BlancaLopez $\mathrm{N}$ et al; ENDA/EAACI Drug Allergy Interest Group. Drug hypersensitivity in children: report from the pediatric task force of the EAACI Drug Allergy Interest Group. Allergy. 2016;71(2):149-61.

7. Abrams EM, Wakeman A, Gerstner TV, Warrington RJ, Singer AG. Prevalence of beta-lactam allergy: a retrospective chart review of drug allergy assessment in a predominantly pediatric population. Allergy Asthma Clin Immunol. 2016;29;12:59.

8. Meng J, Thursfield D, Lukawska JJ. Allergy test outcomes in patients self-reported as having penicillin allergy: Two-year experience. Ann Allergy Asthma Immunol. 2016;117(3):273-9.

9. Romano A. Recognising antibacterial hypersensitivity in children. Paediatr Drugs. 2000;2(2):101-12.

10. Caubet JC, Kaiser L, Lemaître B, Fellay B, Gervaix A, Eigenmann PA. The role of penicillin in benign skin rashes in childhood: a prospective study based on drug rechallenge. J Allergy Clin Immunol. 2011;127(1):218-22.

11. Blanca M, Torres MJ, García JJ, Romano A, Mayorga C, de Ramon E et al. Natural evolution of skin test sensitivity in patients allergic to beta-lactam antibiotics. J Allergy Clin Immunol. 1999;103:918-24.

12. Lucas M, Arnold A, Sommerfield A, Trevenen M, Braconnier L, Schilling A et al. Antibiotic Allergy Labels in Children Are Associated with Adverse Clinical Outcomes. J Allergy Clin Immunol Pract. 2019;7(3):975-82.

13. Macy E. Penicillin and beta-lactam allergy: epidemiology and diagnosis. Curr Allergy Asthma Rep. 2014;14(11):476.

14. Shenoy ES, Macy E, Rowe T, Blumenthal KG. Evaluation and Management of Penicillin Allergy: A Review. JAMA. 2019;321(2):188-99.

15. Torres MJ, Adkinson NF Jr, Caubet JC, Khan DA, Kidon MI, Mendelson Let al; AAAAI/WAO 2018 Symposium Penicillin and Cephalosporin Allergy Testing Working Group. Controversies in Drug Allergy: Beta-Lactam Hypersensitivity Testing. J Allergy Clin Immunol Pract. 2019;7(1):40-5.

16. Blanca M, Romano A, Torres MJ, Férnandez J, Mayorga C, Rodriguez $\mathrm{J}$ et al. Update on the evaluation of hypersensitivity reactions to betalactams. Allergy. 2009;64(2):183-93.
17. Jeffres MN, Narayanan PP, Shuster JE, Schramm GE. Consequences of avoiding $\beta$-lactams in patients with $\beta$-lactam allergies. J Allergy Clin Immunol. 2016;137(4):1148-53.

18. Gerber JS, Ross RK, Bryan M, Localio AR, Szymczak JE, Wasserman R et al. Association of Broad- vs Narrow-Spectrum Antibiotics With Treatment Failure, Adverse Events, and Quality of Life in Children With Acute Respiratory Tract Infections. JAMA. 2017;318(23):2325-36.

19. Macy E, Contreras R. Health care use and serious infection prevalence associated with penicillin "allergy" in hospitalized patients: A cohort study. J Allergy Clin Immunol. 2014;133(3):790-6.

20. Picard M, Bégin P, Bouchard H, Cloutier J, Lacombe-Barrios J, Paradis J et al. Treatment of patients with a history of penicillin allergy in a large tertiary-care academic hospital. J Allergy Clin Immunol Pract. 2013;1(3):252-7.

21. Castells M, Khan DA, Phillips EJ. Penicillin Allergy. N Engl J Med. 2019;381(24):2338-2351.

22. Rubio M, Bousquet PJ, Gomes E, Romano A, Demoly P. Results of drug hypersensitivity evaluations in a large group of children and adults. Clin Exp Allergy. 2012;42(1):123-30.

23. Ponvert C, Perrin Y, Bados-Albiero A, Le Bourgeois M, Karila C, Delacourt $\mathrm{C}$ et al. Allergy to betalactam antibiotics in children: results of a 20-year study based on clinical history, skin and challenge tests. Pediatr Allergy Immunol. 2011;22(4):411-8.

24. Zambonino MA, Corzo JL, Muñoz C, Requena G, Ariza A, Mayorga $\mathrm{C}$ et al. Diagnostic evaluation of hypersensitivity reactions to beta-lactam antibiotics in a large population of children. Pediatr Allergy Immunol. 2014;25(1):80-7.

25. Rebelo Gomes E, Fonseca J, Araujo L, Demoly P. Drug allergy claims in children: from self-reporting to confirmed diagnosis. Clin Exp Allergy. 2008;38(1):191-8.

26. Romano A, Atanaskovic-Markovic M, Barbaud A, Bircher AJ, Brockow K, Caubet JC et al. Towards a more precise diagnosis of hypersensitivity to beta-lactams - an EAACI position paper. Allergy. 2020;75(6):1300-15.

27. Mill C, Primeau MN, Medoff E, Lejtenyi C, O'Keefe A, Netchiporouk E et al. Assessing the Diagnostic Properties of a Graded Oral Provocation Challenge for the Diagnosis of Immediate and Nonimmediate Reactions to Amoxicillin in Children. JAMA Pediatr. 2016;170(6):e160033.

28. Macy E, Vyles D. Who needs penicillin allergy testing? Ann Allergy Asthma Immunol. 2018;121(5):523-9.

29. Collins CA, Choe D, Mochizuki D, Cannavino CR. Evaluating penicillin allergies in children using a standard EMR-based questionnaire. Ann Allergy Asthma Immunol. 2019 ;122(6):6635 .

30. Siew LQC, Li PH, Watts TJ, Thomas I, Ue KL, Caballero MR et al. Identifying Low-Risk Beta-Lactam Allergy Patients in a UK Tertiary Centre. J Allergy Clin Immunol Pract. 2019;7(7):21732181.e1.

31. Romano A, Gaeta F, Arribas Poves MF, Valluzzi RL. CrossReactivity among Beta-Lactams. Curr Allergy Asthma Rep. 2016;16(3):24. 